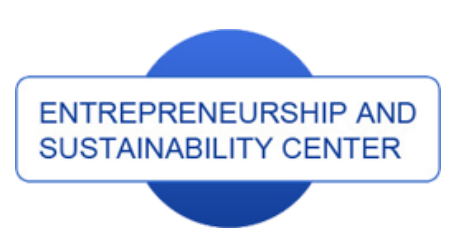

Publisher

http://jssidoi.org/esc/home
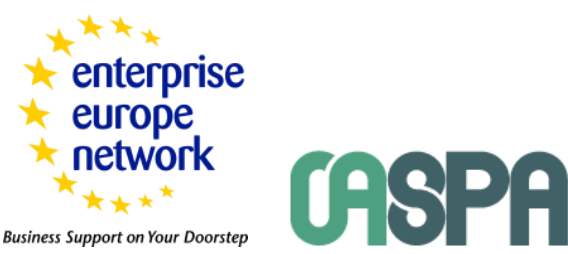

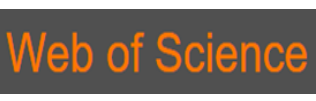

1 Clarivate

Analytics

\title{
INTRA GROUP COMPLIANCE AGREEMENT AS A TOOL TO MANAGE THE RISKS IN THE DAUGHTER COMPANIES *
}

\section{Marek Kordík ${ }^{1}$, Lucia Kurilovská ${ }^{2}$}

\begin{abstract}
${ }^{1,2}$ Department of the Criminal law, Criminology and Criminalistics, Faculty of Law, Comenius University in Bratislava Šafárikovo nám. 6, P.O.BOX 313, 810 00, Bratislava, Slovak Republic
\end{abstract}

E-mail: ${ }^{1}$ marek.kordik(at)flaw.uniba.sk

Received 15 March 2018; accepted 10 June 2018; published 30 June 2018

\begin{abstract}
The contribution deals with the topic of relation ship between the mother company and the daughter company, specifically how to control and verify the compliance rules in the daughters company. The contribution shows the possibility to implement the compliance rules in the daughter company through the so-called intragroup agreement as a frame to set up a correct control, reporting, consequence management in the daughter company as required by the standards of its mother. The research is useful for companies, which operate through various related structures, alliances.
\end{abstract}

Keywords: compliance, effectiveness, criminal responsibility, post-acquisition, SPV, sanctions, vulnerability, mother-company, daughtercompany, intra group relations

Reference to this paper should be made as follows: Kordík, M.; Kurilovská, L. 2018. Intra group compliance agreement as a tool to manage the risks in the daughter companies, Entrepreneurship and Sustainability Issues 5(4): 1008-1019. . http://doi.org/10.9770/jesi.2018.5.4(21)

JEL Classifications: M14, M16

Additional disciplines: law, risk management, compliance

\footnotetext{
* This research has received funding from the Slovak Research and Development Agency Grant Agreement Number APVV15-0740.
} 


\section{Introduction}

In 2014 there were 26.307.386 active business corporations in the EU. ${ }^{1}$ Approx. 2.500 .000 new corporations have been settled within the EU annually. ${ }^{2}$ EUROPOL and EMCDDA estimate the annual size of the EU drug market on $24-31$ billion EURO. ${ }^{3}$ Acc. the EC, the MTIC/VAT tax fraud annual gap is estimated to 5 billion EURO. ${ }^{4}$

The good governance and due care are the tools to avoid the misuse of a corporation for criminal or illegal conducts as mentioned upper through responsible and ethical approach in everyday business. The primary objective of the good governance represents a tool for the constant assess of the compliance maturity of the legal person in order to avoid or to mitigate the risk of criminal liability of the corporation for the past, current and future criminal offences and ensure the constant sustainability of the entrepreneurship in changing environment. Usually dependent on the frame, approach set by the regulatory bodies.

Entering the markets or shall be done directly or indirectly through establishing the SPV or daughter company or buy a control share in the existing one. The newly established daughter company operates suffers from all the problems just like the terms of poor legislation, complicated official procedures to obtain licenses and approvals, and the bureaucratic administration. ${ }^{5}$

Very often the relationship between the public sector and the private sector is still blurred and unclear. There has been no change in the nature of operations between the public and private sectors to enable them to better serve the local community, and accordingly create stability in the investments due to political, geographic, and climatic factors the government is not responsible for. Notwithstanding the existence of a legal framework for the operations of the private sector about business-related procedures, whether related to establishing businesses and other procedures, prolonged litigations and claims. ${ }^{6}$

All these factors raise the risk of corruption, unfair competition, misuse of funds, and breach of trust etc in the newly acquired daughter company. To ensure the same level of compliance and due care driven within its own corporation needs to be applied in a same level also it is daughter corporations, SPV etc. The ration is to mitigate or avoid the responsibility of Mother Company for the illegal conduct subscribed to its daughter. This is done through comprehensive due -diligence in the pre-acquisition phase but as well during post-acquisition phase through implementing mother own standards of due care and compliance.

Business has their own responsibility to act with integrity. Following the notion of corporate social responsibility, companies not only need to comply with laws and regulations; it is increasingly expected that they should also adhere to globally-recognized ethical standards and expectations from society (which might even go beyond the law) as part of their business activities. Assessing whether companies implement anti-corruption ethics and compliance programs within their own operations, promote integrity in their supply chains, publically report on their anti-corruption endeavours, or engage in collective action initiatives with their peers or other stakeholders is therefore also relevant to understanding where a country stands on business integrity. We can summarize the main risks of business criminal practices as following

- criminal offences and financial penalties for the company, imprisonment for directors and managers; ${ }^{7}$

- financial loss to the organization which is caused by paying out in bribes; ${ }^{8}$

- loss of licenses, business reputation and blacklisting, etc. ${ }^{9}$

Adoption of the compliance strategy within an enterprise has a potential to bring benefits to a company. On the one hand, preparation of such a policy would need an extra staff to deal with ethical issues and further costs for program implementation. However, if such a policy would actually function, the costs for its preparation could be regarded as the investment into future savings which would be otherwise paid on damages or leaked out due to irresponsibility of employees and, furthermore, initial costs would be also brought back when a 
company will get more financial opportunities thanks to its reputation improvement due to the fact that it operates with high ethical standards. Even results of a 1999 DePaul University study of 300 large companies indicated that those companies "which made an explicit commitment to follow ethical standards provided more than twice the values to shareholders that com panies that did not". ${ }^{10}$

To sum up, we can talk about the following potentials (Transparency International, 2008)

-enhancement of a company reputation as a business that trades ethically increases its access to national and international markets; ${ }^{11}$

- better prospects to acquire government business; ${ }^{12}$

- better protection of business against legal penalties, blacklisting or loss of licences; ${ }^{13}$

- encouragement of good working relationships and morale; ${ }^{14}$

- not some bribe payer or receiver but the owners will be in real control of their business, ${ }^{15}$

- better management and saving of money which would be otherwise used for bribery or not earned because of inconvenient business. ${ }^{16}$

\section{The need of compliance coming from the European legal framework}

Common market and free movement of men, goods and assets led the new markets to be entered and the new business models to be established. The business relations started to be more structured and complicated. The corporations face tremendous and dynamic press on the compliance of their every-day business with the required standards. Requirements of the due care are set not only by the ISO norms but also by the ability of a mother company establish high level of ethical conduct in its daughters and SPV and, once established, control it.

Recently introduced concept of the criminal responsibility of legal persons starts to be the second part (even more important in many cases). Due to the fact that criminal liability of legal entities ${ }^{17}$ has been introduced in all EU states apart from the Bulgaria, Germany, Greece, Latvia and Sweden ${ }^{18}$, the risk of criminal liability for the corporation materialized if a crime is committed and there is a causal link between the legal entity and a natural person in the exercise of the power to represent that legal person or to exercise the power to take decisions on behalf of that legal person or to exercise the power to exercise control within that legal person or to neglect the supervision or due diligence of that legal person. This concept does not exclude the liability of the mother company to fail to establish effective compliance environment in the daughter company (established or acquired). ${ }^{19}$

In general a legal person is considered to have committed a criminal offence if the criminal offence was committed for its benefit, on its behalf, as part of or through its activities by

(a) its statutory body or a member of its statutory body,

(b) a person performing control or supervision within the legal person, or

(c) another person authorized to represent the legal person or make decisions on its behalf.

(A legal person is considered to have committed a criminal offence also if a person referred to under the letter a) to c) fails, even if by negligence, to properly perform its control and supervision duties, thus allowing a criminal offence being committed by a person acting within the scope of authority conferred by the legal person.

It varies wheatear a legal person shall not be held criminally liable for a criminal offence committed by a person referred above (the employer) if the failure to properly fulfil control and supervision duties by the legal person's body or persons referred to in (a) to (c) is of negligible significance with regard to the object of activity of the legal person and to the manner, consequences and circumstances of the commission of the offence. Criminal liability of a legal person is not usually conditional on whether the natural person referred to a) to c) has been found criminally liable or on whether it has been established which natural person acted in a manner referred. 
As a good example of this practice may be illustrated on the DIRECTIVE 2008/99/EC OF THE EUROPEAN PARLIAMENT AND OF THE COUNCIL of 19 November 2008 on the protection of the environment through criminal law that establishes the obligation of all member States the following conduct constitutes a criminal offence, when unlawful and committed intentionally or with at least serious negligence: ${ }^{20}$

- the discharge, emission or introduction of a quantity of materials or ionizing radiation into air, soil or water, which causes or is likely to cause death or serious injury to any person or substantial damage to the quality of air, the quality of soil or the quality of water, or to animals or plants;

- the collection, transport, recovery or disposal of waste, including the supervision of such operations and the after-care of disposal sites, and including action taken as a dealer or a broker (waste management), which causes or is likely to cause death or serious injury to any person or substantial damage to the quality of air, the quality of soil or the quality of water, or to animals or plants;

- the shipment of waste, where this activity falls within the scope of Article 2(35) of Regulation (EC) No 1013/2006 of the European Parliament and of the Council of 14 June 2006 on shipments of waste and is undertaken in a non-negligible quantity, whether executed in a single shipment or in several shipments which appear to be linked;

- the operation of a plant in which a dangerous activity is carried out or in which dangerous substances or preparations are stored or used and which, outside the plant, causes or is likely to cause death or serious injury to any person or substantial damage to the quality of air, the quality of soil or the quality of water, or to animals or plants;

- the production, processing, handling, use, holding, storage, transport, import, export or disposal of nuclear materials or other hazardous radioactive substances which causes or is likely to cause death or serious injury to any person or substantial damage to the quality of air, the quality of soil or the quality of water, or to animals or plants;

- the killing, destruction, possession or taking of specimens of protected wild fauna or flora species, except for cases where the conduct concerns a negligible quantity of such specimens and has a negligible impact on the conservation status of the species;

- trading in specimens of protected wild fauna or flora species or parts or derivatives thereof, except for cases where the conduct concerns a negligible quantity of such specimens and has a negligible impact on the conservation status of the species;

- any conduct which causes the significant deterioration of a habitat within a protected site;

- the production, importation, exportation, placing on the market or use of ozone-depleting substances.

Member States shall ensure that legal persons can be held liable for the above mentioned offences where such offences have been committed for their benefit by any person who has a leading position within the legal person, acting either individually or as part of an organ of the legal person, based on:

- a power of representation of the legal person;

- an authority to take decisions on behalf of the legal person; or

- an authority to exercise control within the legal person. ${ }^{21}$

Member States shall also ensure that legal persons can be held liable where the lack of supervision or control, by a person referred to in paragraph 1, has made possible the commission of an offence referred above for the benefit of the legal person by a person under its authority. ${ }^{22}$

Member States shall take the necessary measures to ensure that legal persons held liable are punishable by effective, proportionate and dissuasive penalties. ${ }^{23}$

The request to establish liability of legal person for the committed offense is presented in numerous legal texts and tools. It is important to establish whether all legal texts and norms require to establish criminal liability of 
legal persons stricto sensu or it is sufficient to implement the norm in a way of any (mainly administrative) liability for the committed offense.

The conducted analysis has confirmed that not all Framework Decisions and Directives ${ }^{24}$ require the implementation of the direct criminal liability of legal entities as we know them in relation to natural persons. At the same time, however, the analysis confirmed that all European norms that have been analyzed so far require the legal person to be held accountable for the crimes committed. The notion of responsibility in this context is undoubtedly wider and can be interpreted as a criminal offense by a legal person for committing offenses in the form of administrative punishment or indirect criminal liability of legal persons, as critics of direct criminal liability of legal persons put it.

The analyzed international conventions ${ }^{25}$ allow to address the liability of the legal person for offenses and the indirect criminal liability of legal persons or administrative punishment. In their text, they are working on the concept of liability and the imposition of a sanction, not specifying that it is only a penalty. The requirement for conventions is to impose effective and effective sanctions. The requirement of the criminal penalties in the conventions is missing. It implies that the above mentioned Conventions do not require the introduction of direct criminal liability of legal entities, since it is wider in scope and the implementation requirement can be met in the form of administrative punishment.

\section{Oversea (USDOJ) approach}

When a company has voluntarily self-disclosed ${ }^{26}$ misconduct in an FCPA matter, fully cooperated ${ }^{27}$, and timely ${ }^{28}$ and appropriately remediated, all in accordance with the standards set forth below, there will be a presumption that the company will receive a declination absent aggravating circumstances involving the seriousness of the offense or the nature of the offender. Aggravating circumstances that may warrant a criminal resolution include, but are not limited to, involvement by executive management of the company in the misconduct; a significant profit to the company from the misconduct; pervasiveness of the misconduct within the company; and criminal recidivism. ${ }^{29}$

Cooperation comes in many forms. Once the threshold requirements set out at USAM $\S 9-28.700$ have been met, the Department will assess the scope, quantity, quality, and timing of cooperation based on the circumstances of each case when assessing how to evaluate a company's cooperation under the FCPA Corporate Enforcement Policy. ${ }^{30}$

Disclosure on a timely basis of all facts relevant to the wrongdoing at issue, includes all relevant facts gathered during a company's independent investigation; attribution of facts to specific sources where such attribution does not violate the attorney-client privilege, rather than a general narrative of the facts; timely updates on a company's internal investigation, including but not limited to rolling disclosures of information; all facts related to involvement in the criminal activity by the company's officers, employees, or agents; and all facts known or that become known to the company regarding potential criminal conduct by all third-party companies (including their officers, employees, or agents). ${ }^{31}$ Timely preservation, collection, and disclosure of relevant documents and information relating to their provenance, including ${ }^{32}$

- disclosure of overseas documents, the locations in which such documents were found, and who found the documents,

- facilitation of third-party production of documents, and

- where requested and appropriate, provision of translations of relevant documents in foreign languages; 
The International Journal

ENTREPRENEURSHIP AND SUSTAINABILITY ISSUES

ISSN 2345-0282 (online) http://jssidoi.org/jesi/

2018 Volume 5 Number 4 (June)

http://doi.org/10.9770/jesi.2018.5.4(21)

Where a company claims that disclosure of overseas documents is prohibited due to data privacy, blocking statutes, or other reasons related to foreign law, the company bears the burden of establishing the prohibition. Moreover, a company should work diligently to identify all available legal bases to provide such documents. ${ }^{33}$ Proactive cooperation, rather than reactive means the company must timely disclose facts that are relevant to the investigation, even when not specifically asked to do so, and, where the company is or should be aware of opportunities for the Department to obtain relevant evidence not in the company's possession and not otherwise known to the Department, it must identify those opportunities to the Department; ${ }^{34}$ Where requested, deconfliction of witness interviews and other investigative steps that a company intends to take as part of its internal investigation with steps that the Department intends to take as part of its investigation; and where requested, making available for interviews by the Department those company officers and employees who possess relevant information; this includes, where appropriate and possible, officers, employees, and agents located overseas as well as former officers and employees (subject to the individuals' Fifth Amendment rights), and, where possible, the facilitation of third-party production of witnesses. ${ }^{35}$

If a criminal resolution is warranted for a company that has voluntarily self-disclosed, fully cooperated, and timely and appropriately remediated, the Fraud Section:

- will accord, or recommend to a sentencing court, a 50\% reduction off of the low end of the U.S. Sentencing Guidelines (U.S.S.G.) fine range, except in the case of a criminal recidivist; and

- generally will not require appointment of a monitor if a company has, at the time of resolution, implemented an effective compliance program.

To qualify for the FCPA Corporate Enforcement Policy, the company is required to pay all disgorgement, forfeiture, and/or restitution resulting from the misconduct at issue. To have an effective compliance and ethics program, an organization shall:

- exercise due diligence to prevent and detect criminal conduct; and

- otherwise promote an organizational culture that encourages ethical conduct and a commitment to compliance with the law.

- such compliance and ethics program shall be reasonably designed, implemented, and enforced so that the program is generally effective in preventing and detecting criminal conduct. The failure to prevent or detect the instant offense does not necessarily mean that the program is not generally effective in preventing and detecting criminal conduct.

Due diligence and the promotion of an organizational culture that encourages ethical conduct and a commitment to compliance minimally require the following:

- The organization shall establish standards and procedures to prevent and detect criminal conduct.

- The organization's governing authority shall be knowledgeable about the content and operation of the compliance and ethics program and shall exercise reasonable oversight with respect to the implementation and effectiveness of the compliance and ethics program. ${ }^{36}$

- High-level personnel of the organization shall ensure that the organization has an effective compliance and ethics program Specific individual(s) within high-level personnel shall be assigned overall responsibility for the compliance and ethics program. ${ }^{37}$

- Specific individual(s) within the organization shall be delegated day-to-day operational responsibility for the compliance and ethics program. Individual(s) with operational responsibility shall report periodically to high-level personnel and appropriate, to the governing authority, or an appropriate subgroup of the governing authority, on the effectiveness of the compliance and ethics program. To carry out such operational responsibility, such individual(s) shall be given adequate resources, appropriate authority, and direct access to the governing authority or an appropriate subgroup of the governing authority ${ }^{38}$ 
The International Journal

ENTREPRENEURSHIP AND SUSTAINABILITY ISSUES

ISSN 2345-0282 (online) http://jssidoi.org/jesi/

2018 Volume 5 Number 4 (June)

http://doi.org/10.9770/jesi.2018.5.4(21)

The organization shall use reasonable efforts not to include within the substantial authority personnel of the organization any individual whom the organization knew, or should have known through the exercise of due diligence, has engaged in illegal activities or other conduct inconsistent with an effective compliance and ethics program.

The organization shall take reasonable steps to communicate periodically and in a practical manner its standards and procedures, and other aspects of the compliance and ethics program, to the individuals ${ }^{39}$ by conducting effective training programs and otherwise disseminating information appropriate to such individuals' respective roles and responsibilities. ${ }^{40}$

The organization shall take reasonable steps:

- to ensure that the organization's compliance and ethics program is followed, including monitoring and auditing to detect criminal conduct;

- to evaluate periodically the effectiveness of the organization's compliance and ethics program; and

- to have and publicize a system, which may include mechanisms that allow for anonymity or confidentiality, whereby the organization's employees and agents may report or seek guidance regarding potential or actual criminal conduct without fear of retaliation. ${ }^{41}$

The organization's compliance and ethics program shall be promoted and enforced consistently throughout the organization through ${ }^{42}$

- appropriate incentives to perform in accordance with the compliance and ethics program; and

- appropriate disciplinary measures for engaging in criminal conduct and for failing to take reasonable steps to prevent or detect criminal conduct. ${ }^{43}$

After criminal conduct has been detected, the organization shall take reasonable steps to respond appropriately to the criminal conduct and to prevent further similar criminal conduct, including making any necessary modifications to the organization's compliance and ethics program. Tthe organization shall periodically assess the risk of criminal conduct and shall take appropriate steps to design, implement, or modify each requirement to reduce the risk of criminal conduct identified through this process. ${ }^{44}$

\section{Conclusions- Intra-Group Compliance Agreement as a solution}

Intra-Group Compliance Agreement (further as an "IGCA") is an internal agreement/contract/ memorandum of understanding. The parties of the IGCA should be (obligatory) Mother company (further referred as "MCOMPANY") mainly a limited liability corporation or the stock corporation founded usually under the same or different law as the daughter company (further referred as a "D-COMPANY") in that it holds decisive share to umbrella the organization in its domestic or international activities.

D-COMPANY is usually a limited liability company or a stock corporation under the country law and part of the Group with its direct and indirect shareholdings. M-COMPANY holds the decisive share of D-COMPANY directly. In relation to its shareholdings, as affiliates, D-COMPANY assumes the role of a so-called parent company.

The basic prerequisite to set up the intragroup compliance relationship, is that M-COMPANY has defined the legality of its corporate action (further referred as "Compliance") as one of its central company objectives and established a separate Compliance Management System ( further referred as "CMS") usually under the direction of M-COMPANY's Chief Compliance Officer (further referred as "CCO M-COMPANY”). 
It should be agreed in the IGCA that the CCO should be assisted by the Group Compliance Management (further referred as "GCM") department to support his or her duties, - together they will form the Compliance Office MCOMPANY (further referred as "CO M-COMPANY").

The Group Compliance Officer D-COMPANY (further as "GCO COMPANY") should support D-COMPANY's management in meeting its compliance responsibilities. Under his leadership, D-COMPANY establishes to operate a Compliance Management System (further as "CMS") uniformed to M-COMPANY CMS, which needs to be tailored to the national needs, where necessary. D-COMPANY shall operate a Compliance Program (further as "CP") in this framework.

The IGCA should state that the Group Compliance Officer in his function (further as the GCO D-COMPANY) is also responsible for the cooperation with D-COMPANY's affiliates in compliance matters. For example, the affiliates' Compliance Officers have a duty to report directly to the D-COMPANY and also to the Supervisory Board.

The IGCA should also mention that M-COMPANY and D-COMPANY will cooperate closely on compliance matters in line with the International DRC cooperation/governance model acknowledged by D-COMPANY's Management.

With the goal of implementing the further development of the D-COMPANY Group's compliance organization, which was decided by the D-COMPANY Board of Management, the Parties intend to strengthen and intensify the cooperation.

Notwithstanding that, it should be anticipated that the CO M-COMPANY will support the D-COMPANY in designing and operating its compliance organization by providing central expertise in all matters relating to the provisions of the IGCA.

The cooperation governed by the IGCA should be based on the fact that D-COMPANY's management or the shareholders responsible for its supervision are and shall remain responsible for ensuring compliance.

The cooperation governed by the IGCA should be based on the mutual trust between the M-COMPANY and DCOMPANY. The common high standard of behavior and responsibility of the M-COMPANY and the DCOMPANY precludes, that each submitted request for cooperation meets the legal criteria of the requesting state and M-COMPANY Code of Conduct principles. As well each executed request will meet the legal criteria of the executing state and M-COMPANY Code of conduct principles.

The Parties will furthermore agree that the conclusion of the IGCA shall not alter this responsibility and, in particular, it is not intended to transfer D-COMPANY's responsibility for ensuring compliance to the CCO, CO M-COMPANY or the M-COMPANY Board of Management

\section{References}

${ }^{1}$ Eurostat, structural bussiness statistics, main table, availabale on 25. 10. 2017, na: http://ec.europa.eu/eurostat/tgm/table.do?tab=table\&init=1\&language=en\&pcode=tin00170\&plugin=1

${ }^{2}$ Eurostat, structural bussiness statistics, main table, available on 25. 10. 2017, na: http://ec.europa.eu/eurostat/tgm/table.do?tab=table\&init=1 \&language=en \&pcode=tin00170\&plugin=1 
${ }^{3}$ EMCDDA Strategic EU drug market analyses 2013, available on 25. 10. 2017

http://www.emcdda.europa.eu/system/files/publications/2373/downloads/Technical\%20report_Estimating\%20the\%20size\%2 0of\%20main\%20drug\%20markets.pdf_en

${ }^{4}$ EUROPOL, Annual suspicion to action converting financial intelligence greater operational impact https://www.europol.europa.eu/publications-documents/suspicion-to-action-converting-financial-intelligence-greateroperational-impact

${ }^{5}$ Transparency International's Business Integrity Country Agenda, Transparency International, 2016,16p Available on: https://www.transparency.org/whatwedo/publication/business_integrity_country_agenda_bica_conceptual_framework_for_a _bica_asse on April 3rd, 2018

${ }^{6} J$. David Reitzel; Contemporary Business Law: Principles and Cases; - 4. ed. - New York: McGraw-Hill Publishing Comp., ISBN 0-07-051905-6; 1990. p. 12

${ }^{7}$ Tony Mac Adams; Law, Business, and Society; 2. ed. Homewood: Richard D. Irwin, Inc., ISBN 0-256-07374-0; 1989. p.7 ${ }^{8}$ Klevorick, R.; On the Economic Theory of Crime; in J. Rolland Pennock and John W. Chapman (eds.); Criminal Justice: Nomos XXVII, p. 289-309.

${ }^{9}$ Šatníková, S., Anticorruption policies in the Companies Transparency International Slovakia, 2012, p. 3 Availabable on: http://www.transparency.sk/wp-content/uploads/2010/01/Anti-corruption-policies-in-companies_Satnikova.pdf on April 4th, 2018

${ }^{10}$ CSIS -SFPA, 2005, p. 25, In: Šatníková, S., Anticorruption policies in the Companies Transparency International Slovakia, 2012, p. 3 Availabable on: http://www.transparency.sk/wp-content/uploads/2010/01/Anti-corruption-policies-incompanies_Satnikova.pdf on April 4th, 2018

${ }^{11}$ Gray, CH. W.; Hellman, J.; Rytterman, R.; Anticorruption in Transition 2, Corruption in Enterprise-State Interactions in Europe and Central Asia 1999-2002?; The World Bank, 2004; p.12

${ }^{12}$ Anderson, J.,H.; Gray, CH. W.; Anticorruption in Transition 3, Who is Succeeding....and why?; The World Bank, 2006; p.8

${ }^{13}$ Stessens, G.; Money-laundering- A new international Law enforcement model; Cambridge University Press, 2002, p.40

${ }^{14}$ Goergen, M.; International Corporate Governance; Pearson Education Limited, 2012, p.53

${ }^{15}$ J. David Reitzel; Contemporary Business Law: Principles and Cases; - 4. ed. - New York: McGraw-Hill Publishing Comp., ISBN 0-07-051905-6; 1990. p. 113

${ }^{16}$ The Legal Environment of Business. / F. William McCarthy, John W. Bagby. - Boston: Richard D. Irwin, Inc., ISBN 0256-08482-3, 1990. p.32

${ }^{17} \mathrm{~A}$ 'legal entity' means any legal entity having such status under the applicable national law, except for States or public bodies exercising State authority and for public international organizations. Inter alia Art. 2 of the DIRECTIVE 2008/99/EC OF THE EUROPEAN PARLIAMENT AND OF THE COUNCIL of 19 November 2008 on the protection of the environment through criminal law

${ }^{18}$ Vermuelan G. and Co.; Liability of legal persons for offences in the EU, European commission, DG Justice, 2012 Antwerpen, Maklu, ISBN: 978-80-466-0487-8 p.29; available on 23rd October, 2017 at: https://publications.europa.eu/en/publication-detail/-/publication/e6a11989-48d3-41a1-b4ee-8f7051d84253/language-en. 


\footnotetext{
${ }^{19}$ US DOJ vs. Halliburton https://www.justice.gov/opa/pr/kellogg-brown-root-llc-pleads-guilty-foreign-bribery-charges-andagrees-pay-402-million
}

${ }^{20}$ Art. 3 of the DIRECTIVE 2008/99/EC OF THE EUROPEAN PARLIAMENT AND OF THE COUNCIL of 19 November 2008 on the protection of the environment through criminal law

${ }^{21}$ Art 6.1 of the DIRECTIVE 2008/99/EC OF THE EUROPEAN PARLIAMENT AND OF THE COUNCIL of 19 November 2008 on the protection of the environment through criminal law

${ }^{22}$ Art 6.1 of the DIRECTIVE 2008/99/EC OF THE EUROPEAN PARLIAMENT AND OF THE COUNCIL of 19 November 2008 on the protection of the environment through criminal law

${ }^{23} \mathrm{Art} 7$ of the DIRECTIVE 2008/99/EC OF THE EUROPEAN PARLIAMENT AND OF THE COUNCIL of 19 November 2008 on the protection of the environment through criminal law

${ }^{24}$ COUNCIL FRAMEWORK DECISION 2005/212/JHA of 24 February 2005 on Confiscation of Crime-Related Proceeds, Instrumentalities and Property; DIRECTIVE 2014/42/EU OF THE EUROPEAN PARLIAMENT AND OF THE COUNCIL of 3 April 2014 on the freezing and confiscation of instrumentalities and proceeds of crime in the European Union; Proposal for a DIRECTIVE OF THE EUROPEAN PARLIAMENT AND OF THE COUNCIL on combating terrorism and replacing Council Framework Decision 2002/475/JHA on combating terrorism; Council framework Decision of 28 November 2002 on the strengthening of the penal framework to prevent the facilitation of unauthorized entry, transit and residence (2002/946/JHA); council Framework Decision 2003/568/JHA of 22 July 2003 on combating corruption in the private sector; COUNCIL FRAMEWORK DECISION 2004/757/JHA of 25 October 2004 laying down minimum provisions on the constituent elements of criminal acts and penalties in the field of illicit drug trafficking; DIRECTIVE 2008/99/EC OF THE EUROPEAN PARLIAMENT AND OF THE COUNCIL of 19 November 2008 on the protection of the environment through criminal law; DIRECTIVE 2009/52/EC OF THE EUROPEAN PARLIAMENT AND OF THE COUNCIL of 18 June 2009 providing for minimum standards on sanctions and measures against employers of illegally staying third-country nationals; DIRECTIVE 2005/35/EC OF THE EUROPEAN PARLIAMENT AND OF THE COUNCIL of 7 September 2005 on ship-source pollution and on the introduction of penalties for infringements; Council Framework Decision 2008/913/JHA of 28 November 2008 on combating certain forms and expressions of racism and xenophobia by means of criminal law; COUNCIL FRAMEWORK DECISION 2008/841/JHA of 24 October 2008 on the fight against organized crime; DIRECTIVE 2011/36/EU OF THE EUROPEAN PARLIAMENT AND OF THE COUNCIL of 5 April 2011 on preventing and combating trafficking in human beings and protecting its victims, and replacing Council Framework Decision 2002/629/JHA; DIRECTIVE 2011/92/EU OF THE EUROPEAN PARLIAMENT AND OF THE COUNCIL of 13 December 2011 on combating the sexual abuse and sexual exploitation of children and child pornography, and replacing Council Framework Decision 2004/68/JHA; DIRECTIVE 2013/40/EU OF THE EUROPEAN PARLIAMENT AND OF THE COUNCIL of 12 August 2013 on attacks against information systems and replacing Council Framework Decision 2005/222/JHA;

${ }^{25}$ CONVENTION on combating bribery of foreign public officials in international business transactions adopted by the Negotiating Conference on 21 November 1997; CONVENTION on Laundering, Search, Seizure and Confiscation of the Proceeds from Crime Strasbourg, 8. XI. 1990; COUNCIL OF EUROPE CONVENTION ON LAUNDERING, SEARCH, SEIZURE AND CONFISCATION OF THE PROCEEDS FROM CRIME AND ON THE FINANCING OF TERRORISM Warsaw, 16. V. 2005; CRIMINAL LAW CONVENTION ON CORRUPTION; CONVENTION ON CYBERCRIME Budapest, 23. XI. 2001; COUNCIL OF EUROPE CONVENTION ON THE PREVENTION OF TERRORISM; COUNCIL OF EUROPE CONVENTION ON ACTION AGAINST TRAFFICKING IN HUMAN BEINGS Warsaw, 16. V. 2005; UNITED NATIONS CON VENTION AGAINST TRANSNATIONAL ORGANIZED CRIME; OPTIONAL PROTOCOL to the Convention on the Rights of the Child on the sale of children, child prostitution and child pornography; United Nations Convention against Corruption 


\begin{abstract}
${ }^{26} \mathrm{~A}$ voluntary disclosure qualifies as occurring "prior to an imminent threat of disclosure or government investigation" FCPA Corporaste enforcement Compliance policy, US DOJ, November 29th, 2017, p.1, available at https://www.justice.gov/criminal-fraud/file/838416/download on March 23rd 2018.

${ }^{27}$ The company discloses all relevant facts known to it, including all relevant facts about all individuals involved in the violation of law; FCPA Corporaste enforcement Compliance policy, US DOJ, November 29th, 2017, p.1, available at https://www.justice.gov/criminal-fraud/file/838416/download on March 23rd 2018
\end{abstract}

${ }^{28}$ The company discloses the conduct to the Department "within a reasonably prompt time after becoming aware of the offense," with the burden being on the company to demonstrate timeliness; FCPA Corporaste enforcement Compliance policy, US DOJ, November 29th, 2017, p.1, available at https://www.justice.gov/criminal-fraud/file/838416/download on March 23rd 2018

${ }^{29}$ FCPA Corporaste enforcement Compliance policy, US DOJ, November 29th, 2017, p.1, available at https://www.justice.gov/criminal-fraud/file/838416/download on March 23rd 2018

${ }^{30}$ Note to he USAM § 9-28.720, Available in: FCPA Corporaste enforcement Compliance policy, US DOJ, November 29th, 2017, p.5, available at https://www.justice.gov/criminal-fraud/file/838416/download on March 23rd 2018

${ }^{31}$ USAM § 9-28.720, Available in: FCPA Corporaste enforcement Compliance policy, US DOJ, November 29th, 2017, p.3, available at https://www.justice.gov/criminal-fraud/file/838416/download on March 23rd 2018

${ }^{32}$ Available in: FCPA Corporaste enforcement Compliance policy, US DOJ, November 29th, 2017, p.4, available at https://www.justice.gov/criminal-fraud/file/838416/download on March 23rd 2018

${ }^{33}$ Available in: FCPA Corporaste enforcement Compliance policy, US DOJ, November 29th, 2017, p.4, available at https://www.justice.gov/criminal-fraud/file/838416/download on March 23rd 2018

${ }^{34}$ Available in: FCPA Corporaste enforcement Compliance policy, US DOJ, November 29th, 2017, p.3, available at https://www.justice.gov/criminal-fraud/file/838416/download on March 23rd 2018

${ }^{35}$ Available in: FCPA Corporaste enforcement Compliance policy, US DOJ, November 29th, 2017, p.3, available at https://www.justice.gov/criminal-fraud/file/838416/download on March 23rd 2018

${ }^{36}$ USS Sentencing guideline manual, March 2013,, p. 498 available at: https://www.ussc.gov/sites/default/files/pdf/guidelines-manual/2013/manual-pdf/2013 Guidelines_Manual_Full.pdf

${ }^{37}$ USS Sentencing guideline manual, March 2013, p. 498 available at: https://www.ussc.gov/sites/default/files/pdf/guidelines-manual/2013/manual-pdf/2013 Guidelines_Manual_Full.pdf

${ }^{38}$ USS Sentencing guideline manual, March 2013,, p. 498 available at: https://www.ussc.gov/sites/default/files/pdf/guidelines-manual/2013/manual-pdf/2013_Guidelines_Manual_Full.pdf, on March 9th, 2018

${ }^{39}$ The individuals are the members of the governing authority, high-level personnel, substantial authority personnel, the organization's employees, and, as appropriate, the organization's agents

${ }^{40}$ USS Sentencing guideline manual, March 2013, p. 499 available at: https://www.ussc.gov/sites/default/files/pdf/guidelines-manual/2013/manual-pdf/2013_Guidelines_Manual_Full.pdf , on March 9th, 2018 
The International Journal

ENTREPRENEURSHIP AND SUSTAINABILITY ISSUES

ISSN 2345-0282 (online) http://jssidoi.org/jesi/

2018 Volume 5 Number 4 (June)

http://doi.org/10.9770/jesi.2018.5.4(21)

${ }^{41}$ USS Sentencing guideline manual, March 2013,, p. 499 available at: https://www.ussc.gov/sites/default/files/pdf/guidelines-manual/2013/manual-pdf/2013_Guidelines_Manual_Full.pdf, on March 9th, 2018

${ }^{42}$ USS Sentencing guideline manual, March 2013,, p. 499 available at:

https://www.ussc.gov/sites/default/files/pdf/guidelines-manual/2013/manual-pdf/2013_Guidelines_Manual_Full.pdf, on March 9th, 2018

${ }^{43}$ USS Sentencing guideline manual, March 2013,, p. 499 available at:

https://www.ussc.gov/sites/default/files/pdf/guidelines-manual/2013/manual-pdf/2013_Guidelines_Manual_Full.pdf, on March 9th, 2018

${ }^{44}$ USS Sentencing guideline manual, March 2013, p. 499 available at: https://www.ussc.gov/sites/default/files/pdf/guidelinesmanual/2013/manual-pdf/2013_Guidelines_Manual_Full.pdf, on March 9th, 2018

\section{Aknowledgements}

This research has received funding from the Slovak Research and Development Agency Grant Agreement Number APVV-150740 .

\section{Dr.h.c. Assoc. prof., Dr. Lucia KURILOVSKÁ, PhD.}

Associated professor of the Department of the Criminal law, Criminology and Criminalistics, Faculty of Law, Comenius University in Bratislava, Rector of the Academy of the Police Force in Bratislava, Honoris causa Doctor of the Police academy of the Czech republic, author and co-author of more than 90 studies, contribution and publications printed domestically and abroad, mainly deals with the priciples and basic standards of the criminal proceeding.

https://orcid.org/0000-0002-1008-9067

Assoc. prof., Dr. Marek KORDIK LL.M., PhD. (also as "corresponding author")

Associated professor of the Department of the Criminal law, Criminology and Criminalistics Faculty of Law, Comenius University in Bratislava. Author and co-author of more than 50 papers, studies, textbooks and contributions mainly focused on the money laundering, white collar crime, mutual cooperation in criminal matters, former Management Board Deputy Chair of the EU agency-CEPOL.

https://orcid.org/0000-0002-4290-8354

Register for an ORCID ID:

https://orcid.org/register

Copyright $(\mathcal{O} 2018$ by author(s) and VsI Entrepreneurship and Sustainability Center This work is licensed under the Creative Commons Attribution International License (CC BY). http://creativecommons.org/licenses/by/4.0/ 